\title{
Assessing Community Adaptation Strategies to Floods in Flood-Prone Areas of Urban District, Zanzibar, Tanzania
}

\author{
Badriya S. Nassor ${ }^{1} \&$ Makame O. Makame ${ }^{1}$ \\ ${ }^{1}$ School of Natural and Social Sciences, The State University of Zanzibar, Zanzibar, Tanzania \\ Correspondence: Badria S. Nassor, School of Natural and Social Sciences, The State University of Zanzibar, \\ Zanzibar, Tanzania. Tel: 255-7-7343-7281. E-mail: badriyanassor99@gmail.com
}

Received: March 5, 2021

Accepted: April 14, $2021 \quad$ Online Published: April 19, 2021

doi:10.5539/jsd.v14n3p95

URL: https://doi.org/10.5539/jsd.v14n3p95

\begin{abstract}
Floods disasters around the world have increased for the last 20 years and affected billions of people. The same has been observed in Zanzibar, which resulted in severe impacts in many parts of the urban-west region and affected many people, threaten several lives and caused substantial economic losses. Therefore, this study intended to assess the community adaptation strategies to floods, the genesis of those strategies and the limiting factors for each adaptation strategies in flood-prone areas in the Urban District in Zanzibar, Tanzania. It involved 399 households. Data were collected using an interviewer-administered questionnaire for heads of the households to assess their adaptation strategies. The study discovered that the community has been employing different adaptation strategies to reduce the floods risk at pre, during and after floods. Before flooding is cemented the floor, while during flooding moved to another place and after flooding did the structural repairs of their houses and recommendations to the government on providing necessary support are delineated.
\end{abstract}

Keywords: adaptation, community, flooding, resilience

\section{Introduction}

Climate change and its impacts are the central topics in the global academic discussions and the core topics in political and economic agendas. In recent decades, the world has experienced increasing frequency and intensity of climate change-related disasters (Tran, 2014; Trogrlic et al., 2018). Commonly, hydro-meteorological disasters are the most catastrophic natural disasters (Dalu et al., 2018). Floods are the most prevailing climate changerelated disaster of hydro-meteorological genesis, which accounts for $9 \%$ of all the deaths originating from natural disasters whereas the affected population from flooding amount to more than 2.2 billion people annually (Jonkman and Kalman, 2005; Tripathi, 2015). The substantial increase of floods occurrence globally resulted in significant loss of economy and life, especially in terms of access to clean and safe water for drinking (GFDRR, 2016; Bottazzi, et al., 2018). Comparatively, the socio-economic impacts of floods on communities have been greater than the impact of other natural disasters (GFDRR, 2018).

Most of the African cities and rural are severely inundated nearly every year from the heavy rainfalls (Dalua, 2018). However, the impacts of the floods have strongly been experienced in the urban areas comparing to the rural. This is because of high population density, poverty levels, urbanization, informal settlements and poor waste management, to mention a few. These are the primary driving factors that increase urban exposure to flooding especially in the developing world (World Bank, 2008; Trogrlic, 2018). Moreover, in East African coast countries floods affecting urban and rural communities to varying degrees, Zanzibar being not an exception. According to Zanzibar Disaster Risk Management Report of 2017, floods prone areas in Unguja include: Mtumwajeni, Kibonde Mzungu, Sebleni, Fuoni Jangamizini, Mwera Kikokani (Bwawa la Mkaro), Kiembesamaki (near the airport), Mwanakwerekwe, Ziwamaboga, Jang'ombe, Mshelishelini, Mombasa, Nyerere, Kidombo, Chwaka Mwanamwema and Mpendae.

Most of the potential measures of floods control are costly and difficult to implement. Often, the focus has been directed towards reducing floods' vulnerability through adopting pre- or post-disaster measures (ASFPM, 2012). Several adaptation measures have been proposed in different affected countries around the world to limit the economic impacts from floods and to reduce the floods risks. Such adaptation measures include rainwaterretention/harvesting facilities to promote runoff reduction and to reduce the overflow of water, awareness programs and preparedness campaign at the floods affected areas, land management plans such as afforestation, increasing 
the level of the homestead and using sandbags in the backyard to protect edge erosion, and building makeshift high platforms at homes (Alfieril et al., 2016; Sheheli, 2015; Tripathi., 2015; Yamashita et al., 2015).

Example Sangkrah in Indonesia and keko machungwa Dar esaalam in Tanzania the community employed different measures to reduce the flood risk include; the use of sandbags, raised plinth, seasonal displacement, provision of doors stairs, protective wall (Sarkijege et al., 2014). Also, the communities found in the West Rapti River Basin of Nepal employed different measures to reduce the floods and associated risks such as; flood forecasting, provision of early warning information for the upcoming flood and temporary change the location during the flood ( Devkota et al., 2014), However, these adaptation measures are lacking blends between two approaches (topdown and bottom-up approaches), where community-based adaptation has been discussed for nearly10 years, but there are still tensions about how to implement or integrate it fully within formal climate adaptation policies. Hence, successful adaptation to climate change needs a new mix of inquiry approaches (Forsyth, 2013).

Floods impacts in Zanzibar have been reported to increase almost every year. It is usually for the communities living in the commonly flooded areas to evacuate their homes during heavy rains every year, it is often that schools located in floods prone areas are closed and some roads are flooded with rainwater (Tanzania floods report, 2016; ZDMC, 2017). In Zanzibar, some measures have been employed to reduce floods associated risk. In this study we intend to assess the community adaptation strategies to floods; a) Community adaptation measures Pre-flooding b) Community adaptation measure during -flooding c) Community adaptation measure post-flooding in floodprone areas in Urban District in Zanzibar, Tanzania

\section{Study Area}

This study was carried out in three Shehias/wards; Nyerere, Kwa Wazee and Jan'gombe, which are amongst the flood's prone areas in the Urban District of Unguja. Their total populations are respectively 8,528, 6,635 and 6,122 and the number of households in the three communities are 957, 1,022 and 918, respectively (URT, 2013). Geographically (Figure 1), these shehias located in the low laying basin which make them more vulnerable to floods and floods related risks and are periodically inundated through receiving runoffs from surrounding during rainy seasons.

Formerly, the areas of Nyerere and Kwa Wazee were cultivation lands and they were not for settlement use. The soils of these areas are often wet and waterlogged. However, due to urban sprawling and unplanned squatter settlements which are fuelled by rapid population increase and urbanization, the areas have now been commonly and every year flooded during rainy seasons and the communities in these areas have been facing several floods risks and impacts. For instance, the heavy rainfall of 2007 caused devastating damage to more than 100 households (ZDMC, 2017). 


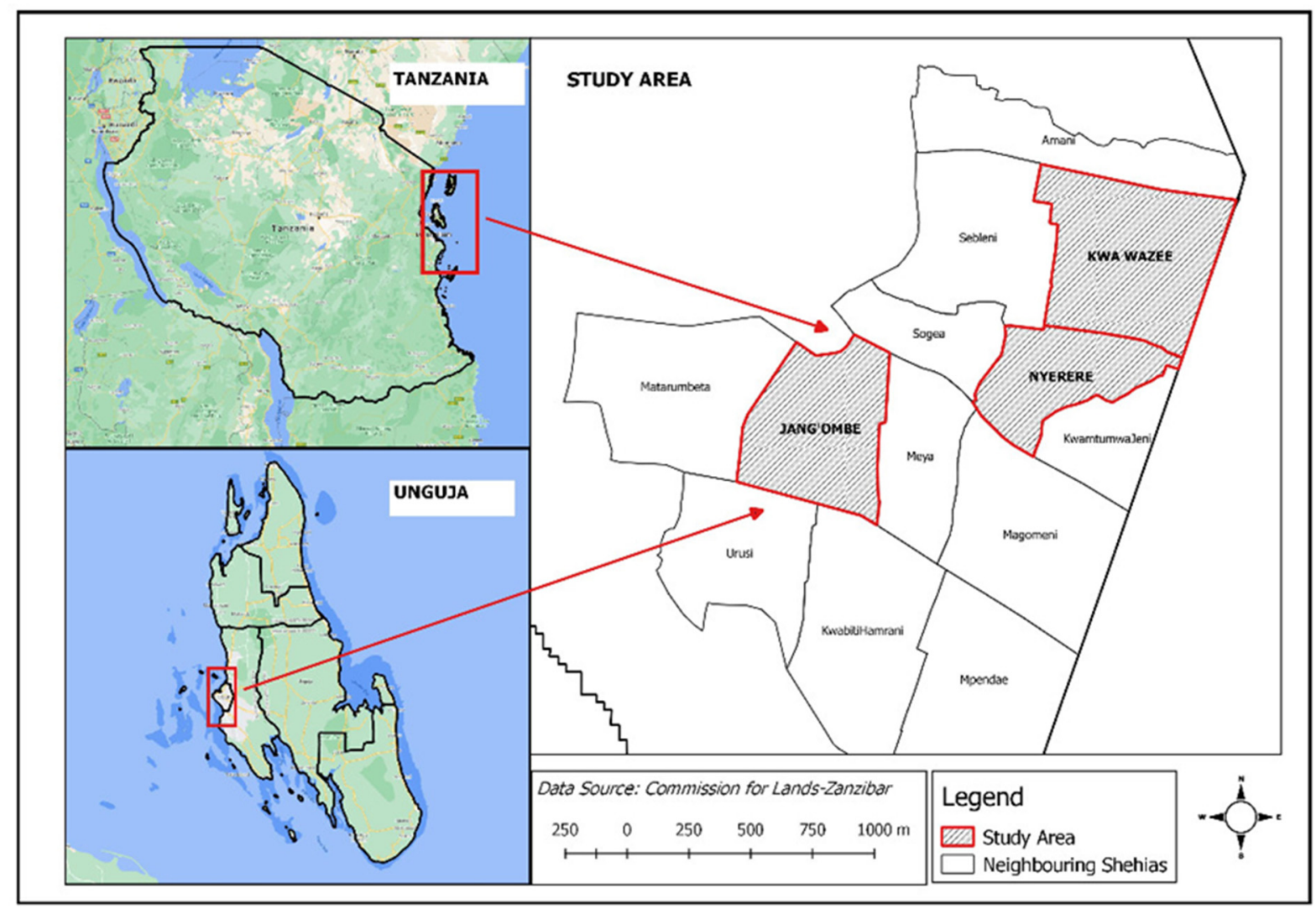

Figure 1. Location of the study site in Unguja Island

\section{Methods}

The research design of this study was a descriptive cross-sectional approach, which employed quantitative approaches. The study was set to determine the adaptation strategies employed by the communities and develop a better understanding of the strategies in an attempt to build strong communities' resilience to the floods problem. The targeted population was all heads of households or any other respondent available in the house with age above 18 years; who was able to give better description or information about floods adaptations.

The total sample size for this study was 399 and was randomly selected at the household level. The proportion of household samples from Shehia of Nyerere was 132, Shehia of Kwa Wazee was 141 and that of Shehia of Jan'gombe was 126. Primary data were gathered via Surveyed method using questionnaires tool which composed of both close-ended and open-ended sets of questions. The data were processed and analysed using SPSS (Statistical Package for Social Science). Descriptive statistics (frequency, percentage, mean and standard deviation) were calculated and interpreted from variables. Also, the spearmen correlation was used to establish the relationship between variables that are related to community floods adaptation strategies with independent variables (socio-demographic characteristics and flood experience).

\section{Results and Discussion}

\subsection{Flood Adaptation Strategies}

\subsubsection{Flood Adaptation Strategies at the Community Level}

After floods experiences and associated stresses, communities across all three sites have tried to find a means to protect themselves and their properties. Therefore, they have been working together to employ different adaptation measures to reduce those floods risks whereby about $70.9 \%$ of household respondents participated. For those who did not participate in community adaptation issues, about $92.6 \%$ had replied that they do not have enough time to participate in social activities as most of their times spent at their working places while $74.1 \%$ did not have a good relationship with their neighbours, and the least reason that was a concern of $45.2 \%$ of the respondents was lack 
of finance to engage in any kind of adaptation that needs resources. This differs from the findings observed by John (2020) who did a study in Dar es Salaam City, Tanzania and found the existence of opportunities like strong social networks, organized communities, and the presence of various local institutions willing to support household responses to floods. Also, the study done by Shaw (2006) in Bangladesh and Vietnam, had discovered that the poor vulnerable communities cannot develop strong coping mechanisms of their own until they get support from local governments due to their low levels of income and lack of information and adaptation skills.

The common measure taken by all communities was waste management $(69.6 \%)$ which involves cleaning the surrounding environment and reduces the solid waste which is the main source of drainage blockage. The second measure identified was placing sand and stones across the areas $(58.1 \%)$, to increase water permeability. The other measure was constructing cement floor in front of houses (20.6\%) to reduce the level of stagnated water. Also, another measure was constructing walls by join houses to block water entrances (18.2\%), planting grasses around areas $(28.5 \%)$ to reduce soil erosion and increase seeps of water into the soil. The least reported measure was creating minor drainage (8.7\%), similarly supported by the study done by Sakijege et al., (2009). Table 1 represents the findings on community actions before flooding.

Table 1. Community actions before flooding $(\mathrm{N}=399)$

\begin{tabular}{lll}
\hline Parameter & Frequency & Percent \\
\hline Community adaptation & & \\
There are not any community flood adaptation strategies & 88 & 22.1 \\
There are different flood measures employed by community & 283 & 70.9 \\
I don't know if there are any community flood adaptation strategies & 28 & 7.0 \\
Total & $\mathbf{3 9 9}$ & $\mathbf{1 0 0 . 0}$ \\
Community flood measures & & \\
Cement floor & 52 & 20.6 \\
Waste management & 176 & 69.6 \\
Wall & 46 & 18.2 \\
Minor drainage & 22 & 8.7 \\
Grasses & 72 & 28.5 \\
Sand and stones & 147 & 58.1 \\
Others (wall hole, steps) & 13 & 5.1 \\
& & \\
Reasons why they do not participate & & \\
Lack of financial & & \\
Low social capital & 61 & 45.2 \\
I don't have time & 100 & 74.1 \\
Others (government responsibility.) & 125 & 92.6 \\
& 22 & 16.3 \\
\hline
\end{tabular}

It was observed that the coping mechanisms by local communities to minimize floods impacts extend to: the use of sandbags, the construction of retaining walls, raising foundations of houses, raising plinths and many others as demonstrated in Figure 2. 


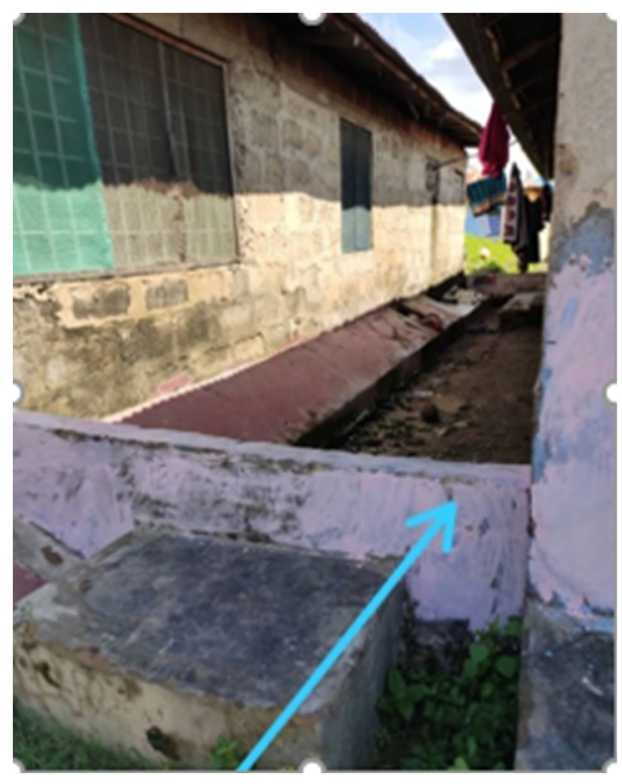

(a)

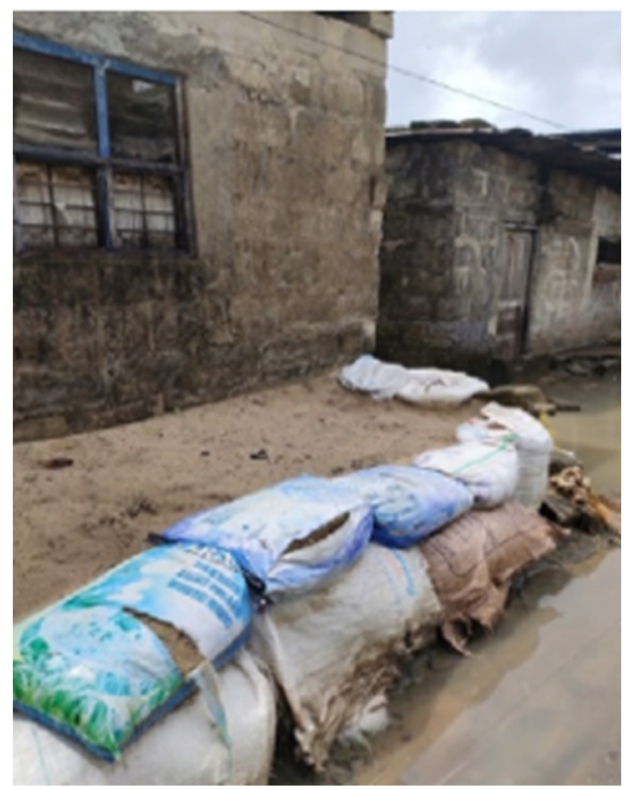

(c)

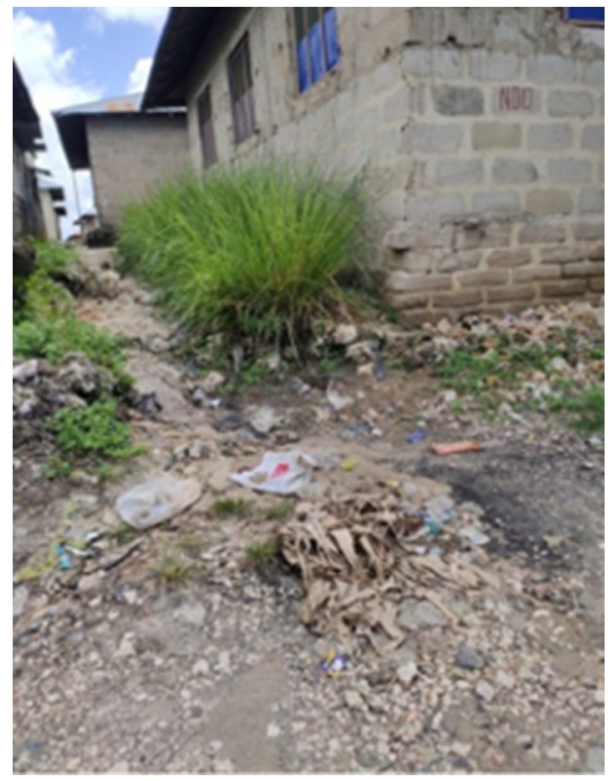

(b)

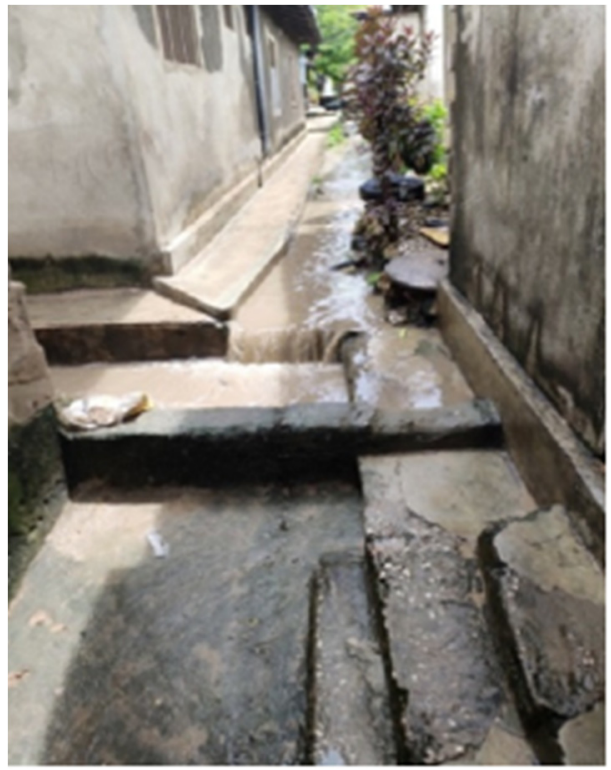

(d)

Figure 2. Flood adaptation strategies at the community level (a) wall construction (b) grass planting (c) sack of sand (d) minor drainage

\subsubsection{Adaptation Strategies at Households' Level}

This study revealed that there are floods adaptation measures employed by each household. As depicted in Table $2,82.5 \%$ of the respondents took various measures to decrease the upcoming floods damages including temporary changing the location (38.8\%), construction of platform around houses $(31.7 \%)$ to reduce the high water level force so as not to reach houses, and creation of door wall floods barrier with steps $(28.9 \%)$ to stop the water from entering their houses. Other mechanisms were the use of car tires $(24.2 \%)$, placing sand and stones around houses $(22.4 \%)$ and grasses $(22.0 \%)$ to control soil erosion, increasing water permeability, increasing levels of housing during construction $(7.5 \%)$, fencing around their houses $(17.4 \%)$, and creation of local minor drainages to create water pathways to reduce water being stagnated or lodging (4.0\%). The least mentioned measure was building walls using strong cement to reduce the penetration of water in the houses $(2.8 \%)$. There are other methods like the use of doormats and culverts in the same way sand and stones are used (14.2\%). Similar results were presented 
by Bakari (2016) who did a study at Shehias of Mwanakwerekwe and Sebuleni, Zanzibar.

Also, a more statistical test was done to find the relationship between variables that are related to household floods adaptation strategies with independent variables (socio-demographic characteristics and flood experience). Table 2 reveals that there is a significant relationship $(p<0.05)$ between placing sand and stones around homes and level of education. Those with secondary level of education accounts for $30.4 \%$, with p-value $=0.021$. The level of education was the most important factor that contributes to the provision of knowledge to the community concerning floods risk and means to reduce risk. This knowledge is acquired through either formal or informal processes, after which they can easily practice in their real situations. This is parallel with studies done in Pakistan that revealed that education is one of the significant factors to minimize floods vulnerability and strengthening the community adaptive capacity (Shah et al., 2018 and Hamidi et al., 2020). Moreover, Nyakundi (2010) in Kenya agrees with this relationship for those educators having the ability to search diversified sources of floods related information.

Moreover, Table 2 shows that house owning status influences the household floods adaptation such as the construction of fencing and platform, with $p$ value $=0.000$ and 0.016 , respectively. This implies that those who own their houses even if they have low wages; take efforts to protect their properties to stop the situation from becoming worse. However, this is different from the study of Fielding (2012) in England and Wales which reported that house owners had no significance on any floods risk due to the existence of house insurance and compensation after damage.

Additionally, Table 3 shows that there is a significant relationship between temporary changing of location and the experience of the floods (the frequency that floods occur per year) and about $69 \%$ of those who change their locations during floods are expected to experience more than two times, with $\mathrm{p}=0.006$. Also, there was a significant relationship between the use of strong cement on their walls and the experience of the floods whereby only $3.5 \%$ responded more than two times, while no one responded twice a year, with $\mathrm{p}=0.03$. This indicates that people who experience many floods are the ones who seriously take actions to cope with the situation because they fear other floods incidences. Similar results were presented by Mulwa (2013) and later confirmed by Næsset al., (2005).

Table 2. Households action before flooding $(\mathrm{N}=399)$

\begin{tabular}{lll}
\hline Parameter & Frequency & Percent \\
\hline Household flood control measures & & \\
There are no household flood control measures & 70 & 17.5 \\
There are household flood control measures & 329 & 82.5 \\
Total & $\mathbf{3 9 9}$ & $\mathbf{1 0 0 . 0}$ \\
Household flood control measures & & \\
Increase the level of the house & 24 & 7.5 \\
Fencing & 56 & 17.4 \\
Sand and stones & 72 & 22.4 \\
Temporal changing of location & 125 & 38.8 \\
Platform & 102 & 31.7 \\
Door wall flood barrier & 93 & 28.9 \\
Grasses & 71 & 22.0 \\
Car tire & 78 & 24.2 \\
Strong cemented wall & 9 & 2.8 \\
Others & 46 & 14.2 \\
Total & $\mathbf{6 7 6}$ & $\mathbf{2 0 9 . 9}$ \\
Reasons to choose that kind of adaptation & & \\
Cheap & 119 & 39.1 \\
Availability of materials & 71 & 23.4 \\
Appropriate to my house & 223 & 73.4 \\
Total & $\mathbf{4 1 3}$ & $\mathbf{1 3 5 . 9}$ \\
\hline
\end{tabular}


The study has also discovered that there are reasons for households to choose the kinds of adaptations, whereby $73.4 \%$ of the respondents chose the reason because it is appropriate to their houses, while $39.1 \%$ chose because of the cost of the method for them to compare with other methods and the least reason favoured by $23.4 \%$ was the availability of materials. This denotes that different factors facilitate the types of adaptation mechanism whereby appropriateness, cost, and availability of materials were chosen, in the order. For example, a temporary change of location is a method employed by many households because it is cheaper. This is because, during floods, the whole areas are covered by water and therefore, it becomes difficult for people to engage other methods. Shifting soon after receiving early warning information could be the best choice as the method does not need much money or resources to implement. This is supported by the study done by Murtinho (2016) at Colombian in the Eastern mountain ranges of the Andes which concluded that the income and poverty levels significantly influence action to implement adaptation strategy.

Table 3. shows the statistical correlation of socio-demographic characteristics and floods experience with individual household's adaptation strategies

\begin{tabular}{|c|c|c|c|c|c|c|c|c|c|}
\hline \multirow{2}{*}{$\begin{array}{l}\text { Demographic } \\
\text { characteristic\& } \\
\text { Flood experience }\end{array}$} & \multicolumn{9}{|c|}{ Household Adaptation } \\
\hline & $\begin{array}{l}\text { Platfor } \\
\text { m }\end{array}$ & $\begin{array}{l}\text { level of the } \\
\text { house }\end{array}$ & $\begin{array}{l}\text { changing } \\
\text { of location }\end{array}$ & $\begin{array}{l}\text { Sand and } \\
\text { Stones }\end{array}$ & Fencing & $\begin{array}{l}\text { Strong } \\
\text { cement }\end{array}$ & $\begin{array}{l}\text { minor } \\
\text { drainage }\end{array}$ & car tires & door wall \\
\hline \multicolumn{10}{|l|}{ Education } \\
\hline In formal & $86(76)$ & $7(6.2)$ & $86(76.1)$ & $18(15.9)$ & $15(13.3)$ & $2(1.8)$ & $1(0.9)$ & $18(15.9)$ & $30(26.5)$ \\
\hline Primary & $37(71)$ & $3(5.8)$ & $37(71.2)$ & $9(17.3)$ & $8(15.4)$ & $1(1.9)$ & $2(3.8)$ & $12(23.1)$ & $13(25.0)$ \\
\hline Secondary & $137(7)$ & $12(6.8)$ & $137(77.4)$ & $27(30.4)$ & $23(13.0)$ & $4(2.3)$ & $8(4.5)$ & $38(21.6)$ & $38(21.6)$ \\
\hline College/ & $36(64)$ & $2(3.6)$ & $36(64.3)$ & $17(15.3)$ & 19(17.9) & $2(3.6)$ & $2(3.6)$ & $10(17.9)$ & 11(19.6) \\
\hline \multicolumn{10}{|l|}{ University } \\
\hline $\mathrm{X}^{2}$ value & 4.653* & $1.808 * *$ & $1.815^{*}$ & $11.575 *$ & $1.133^{*}$ & $2.318^{* *}$ & $4.402^{* * *}$ & $2.407 *$ & $0.345^{*}$ \\
\hline p-value & 0.325 & 0.907 & 0.770 & 0.021 & 0.889 & 0.921 & 0.359 & 0.661 & 0.557 \\
\hline \multicolumn{10}{|l|}{ Income } \\
\hline $0-100000$ & $28(22)$ & $12(9.8)$ & $38(30.9)$ & $22(17.9)$ & $17(13.8)$ & $2(1.6)$ & $4(3.3)$ & $26(21.1)$ & $28(22.8)$ \\
\hline 100001-200000 & $27(23)$ & $6(5.3)$ & $39(34.5)$ & $13(11.5)$ & $11(9.7)$ & $2(1.8)$ & $3(2.7)$ & $29(25.7)$ & $31(27.4)$ \\
\hline 200001-300000 & $17(23)$ & $1(1.4)$ & $23(32.4)$ & $14(19.7)$ & $12(16.9)$ & $1(1.4)$ & $2(2.8)$ & $13(18.3)$ & $14(19.7)$ \\
\hline $300001-400000$ & $23(35)$ & $3(4.7)$ & $16(25.0)$ & $18(28.1)$ & $11(17.2)$ & $3(4.7)$ & $3(4.7)$ & $7(10.9)$ & $15(23.4)$ \\
\hline 400001 and above & $5(20.8)$ & $1(4.2)$ & $8(33.3)$ & $4(16.7)$ & $4(16.7)$ & $0(0.0)$ & $1(4.2)$ & $3(12.5)$ & $3(12.5)$ \\
\hline $\mathrm{X}^{2}$ value & $4.689 *$ & $5.745 * *$ & $1.815 *$ & $7.856^{*}$ & $2.900^{*}$ & $2.326^{* * *}$ & $1.188^{* * *}$ & $6.668^{*}$ & $3.187^{*}$ \\
\hline p-value & 0.321 & 0.186 & 0.770 & 0.097 & 0.575 & 0.685 & 0.918 & 0.154 & 0.527 \\
\hline House ownership & $75(30)$ & $19(7.7)$ & $81(32.7)$ & $49(19.8)$ & $48(19.4)$ & $8(3.2)$ & $9(3.6)$ & $56(22.6)$ & $55(22.2)$ \\
\hline Own Rent & $27(18)$ & $5(3.4)$ & $41(27.9)$ & $21(14.3)$ & $7(4.8)$ & $1(0.7)$ & $4(2.7)$ & $21(14.3)$ & $36(24.5)$ \\
\hline $\mathrm{X}^{2}$ value & $7.714^{* *}$ & $3.050 * *$ & $4.243^{* *}$ & $4.610^{* * *}$ & $19.107^{*}$ & $3.310 *$ & $0.721 * *$ & $4.480 * *$ & $2.099 * *$ \\
\hline p-value & 0.016 & 0.249 & 0.094 & 0.079 & 0.000 & 0.236 & 0.803 & 0.087 & 0.310 \\
\hline \multicolumn{10}{|l|}{$\begin{array}{l}\text { frequent does flood } \\
\text { occur }\end{array}$} \\
\hline Twice a year & $35(25)$ & $9(6.4)$ & $56(40.0)$ & $20(14.3)$ & $17(12.1)$ & $0(0.0)$ & $6(4.3)$ & $32(22.9)$ & $55(22.2)$ \\
\hline $\begin{array}{l}\text { More than two } \\
\text { times }\end{array}$ & $67(25)$ & $15(5.8)$ & $69(26.6)$ & $52(20.1)$ & $39(15.1)$ & $9(3.5)$ & $7(2.7)$ & $46(17.8)$ & $36(24.5)$ \\
\hline $\mathrm{X}^{2}$ value & $0.036^{*}$ & $0.065 *$ & 7.539* & 2.061* & $0.640 *$ & $4.723^{* *}$ & 3.187* & $1.501 *$ & $0.345^{*}$ \\
\hline p-value & 0.849 & 0.798 & 0.006 & 0.151 & 0.424 & 0.030 & 0.392 & 0.221 & $\mathbf{0 . 5 5 7}$ \\
\hline
\end{tabular}




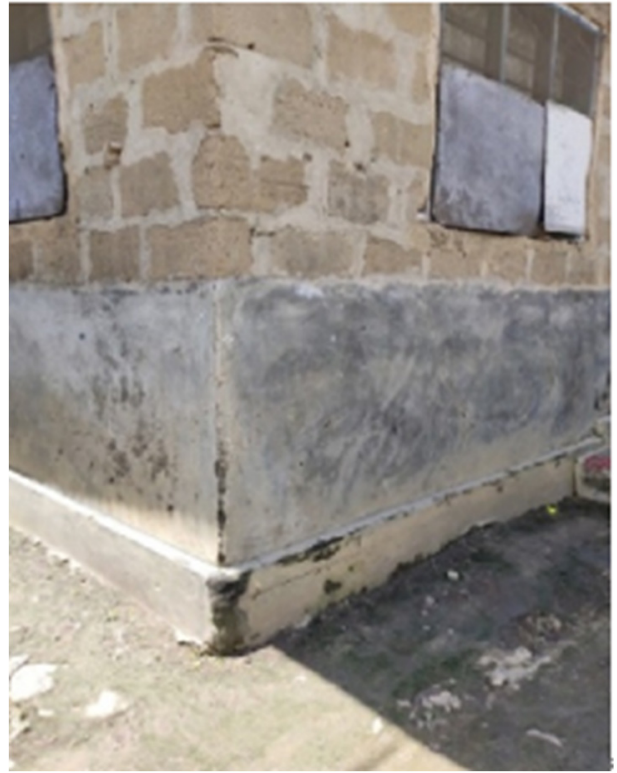

(a)

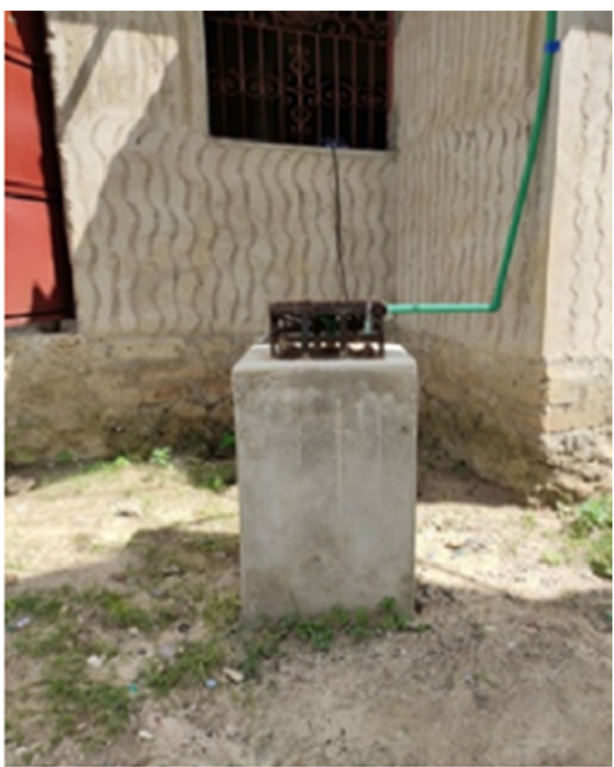

(c)

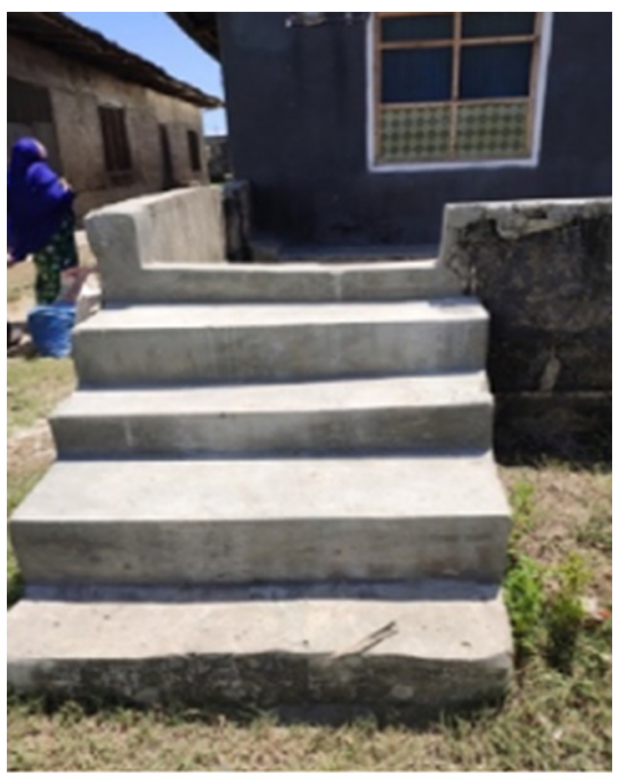

(b)

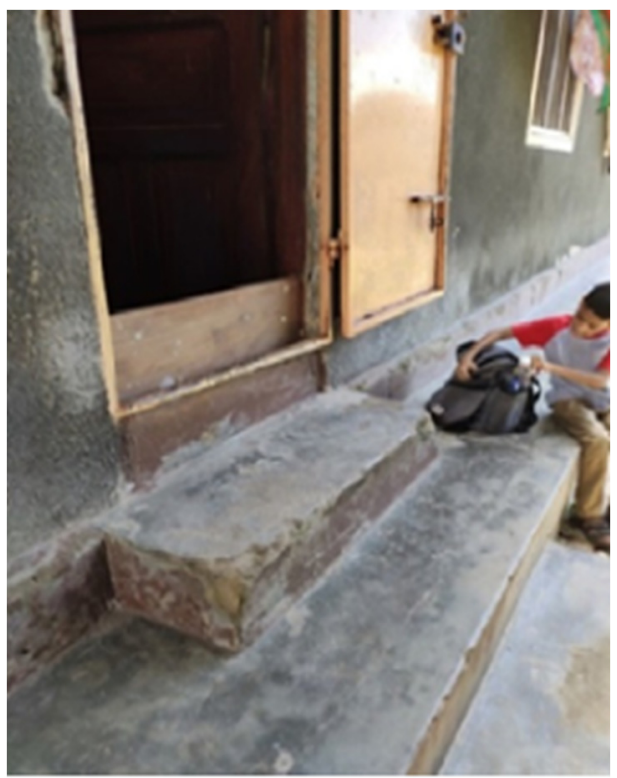

(d)

Figure 3. Flood adaptation strategies at households' level (a) strong cement wall (b) wall and stairs (c) raising water level (d) wooden barrier

\subsubsection{Action during Flood}

Due to unprecedented rainfall, sometimes floods can happen in flash without warning. Therefore, when there is flash extreme flooding, communities took various actions to save their lives and their properties. The action and reaction taken during floods are presented in Table 4, whereby immediately after floods had happened, $86 \%$ of the respondents had taken various actions to save their lives including shifting to other safe places (54.4\%), continuing to stay and just put things up (26.3\%), and sending items to other places (5.5\%). For those who move during floods, about 39.3\% mentioned that they moved to their relatives' houses, $10.8 \%$ moved to their neighbor's houses and only $3.5 \%$ moved to collective centers such as schools and other government public centers. This is similar to the study of Devcota et al., (2014) in Nepal that showed that the community had used their local knowledge to forecast 
the flooding such as the movement of cloud and therefore, they had prepared a temporary location to rescue themselves. Also, in both areas within the communities of Kenya and Central Africa, their main adaptation strategy for floods is temporary relocation (Nguimalet, 2018). Further, the study of Danso and Addo (2016) at SekondiTakoradi Metropolis, in Ghana suggests that mutual coping strategies adopted by residents in all the communities were temporary relocation of homes, transfer of properties to neighbor's and building of floods steps. Further, this finding also supported by the study of Munyai et al., (2019) which discovered that appropriate coping strategies of the communities in Makhado Municipality in South Africa were a temporary change of the location and waiting for the neighbours and government help. However, this different from the Asia Pacific Project (2018) in Nepal whereby the two communities in Sapatri District at Eastern and Rautahat District in Central Nepal had both the areas affected by river flooding and the community floods committee helped the community to face floods difficulties and become resistant to the situation.

Table 4. Action during floods $(\mathrm{N}=399)$

\begin{tabular}{lcc}
\hline Parameter & Frequency & Percent \\
\hline Action during flood & 56 & 14 \\
I do not take any action & 343 & 86 \\
I take action & 399 & 100 \\
Total & & \\
Action during flood & 217 & 54.4 \\
Moving to another place & 105 & 26.3 \\
Continues to stay and put things up & 22 & 5.5 \\
Send my items to another place & 55 & 13.8 \\
Missing 999 & 399 & 100 \\
Total & & \\
Action during the flood (moving & & \\
to other places) & 157 & 39.8 \\
My relatives & 43 & 10.8 \\
My neighbours & 14 & 3.5 \\
Collective center/Public area & 185 & 46.4 \\
Missing 999 & 399 & 100 \\
Total & & \\
\hline
\end{tabular}

\subsection{Action at Post Flooding}

The study findings have revealed that $57.4 \%$ of the respondents do not make any repair from the damages caused by floods; they just clean and return to their houses. This is due to different reasons that respondents mentioned including lack of financial resources to buy materials and pay for technicians for maintenance (94.0\%). Normally, floods damages are so huge that make some developed countries set risk insurances; which is not always the case for developing countries where they only depend on the continuous support of donors like the Organization for Economic Co-operation and Development (OECD). This was supported by John (2020) who did a study in Dar es Salaam City, Tanzania was reported that the community need support to overcome floods risks. More details are shown in Table 5. 
Table 5. Action at post-flooding $(\mathrm{N}=399)$

\begin{tabular}{lll}
\hline Parameter & Frequency & Percent \\
\hline After floods damages & & \\
No any structural repair & 229 & 57.4 \\
Structural repair & 170 & 42.6 \\
Total & 399 & 100.0 \\
Reasons not to repair & & \\
Lack of financial resources & 203 & 94.0 \\
I don't know what to do & & \\
Total & 78 & 36.1 \\
& 281 & 130.1 \\
Repaired cost & & \\
0-49000 & 33 & 8.3 \\
50000-99000 & 56 & 14.0 \\
100000-149000 & 38 & 9.5 \\
150000-199000 & 25 & 6.3 \\
200000 and above & 22 & 5.5 \\
Missing 999 & 225 & 56.4 \\
Total & 399 & 100.0 \\
\hline
\end{tabular}

\section{Conclusion}

The general objective of this study was to assess the community adaptation strategies to floods with floods prone areas of the urban district in Zanzibar, Tanzania being a case study and the three Shehias of Nyerere, Kwa Wazee and Jan'gombe selected as sites for data collection. The study found that communities across all three sites have been experiencing floods almost every rain season. Such floods have left the people with significant economic and life losses. Therefore, concerning this situation, the study indicates that there are several measures that communities employ to adapt to the situation. However, the levels of adaptation differ from one household to another and it is far encouraged by age, level of education, house ownership, duration of staying and the floods experience. This shows that education is a key parameter to any adaptation program. Also, the study has discovered the involvement of the government and private organizations to engage in some measures to save the community lives and their properties. Nevertheless, the support is not adequate. Subsequently, more effort is needed to reduce the floods persisting damages. Therefore, the Government should ensure that floods risks reduction is at the top of national and local priorities with strong institutional bases for implementation. This means the two levels have to work collaboratively as a team to solve the floods problems and must fall under joint efforts of the central government, the local government and the community under context.

\section{References}

Alfieri, L., Feyen, L., \& Di Baldassarr, G. (2016). Increasing flood risk under climate change: A Pan-European assessment of the benefits of four adaptation strategies, Climatic Change. https://doi.org/10.1007/s10584016-1641-1

Ame, A. W. (2015). Assessment of the institutional framework for disaster management in Zanzibar: the case of the west district; A dissertation submitted in partial fulfilment for the requirements for the degree of Master of Arts in social work of the open university of Tanzania.

Asia-Pacific Network for Global Change Research. (2018). Appropriate Solid Waste Management towards Flood: Risk Reduction through Recovery of Drainage Function of Tropical Asian Urban Cities. Final Technical Report. CRRP2016-07MY-Ishigaki. Retrieved from www.apngcr.org/resources/

Association of State Floodplain Managers (ASFPM). (2012). National Committee on LeveeSafety (NCLS). Retrieved from http://www.floods.org/index.asp?menuID=338 
Bakar, A. H. (2016). Assessment of Flood Awareness among Residents Living at Sebleni and Mwanakwerekwe, Zanzibar. Thesis Submitted to Complete Master of the Disaster Management University of Copenhagen.

Bottazzi, P., Winkler, M., Boillat, S., Diagne, A., Sika, M., Kpangon, A., Faye, S., \& Speranza, C. (2018). Measuring Subjective Flood Resilience in Suburban Dakar: Before-After Evaluation of the "Live with Water" Project. Sustainability, 10, 2135. https://doi.org/10.3390/su10072135

Bushesha, M., \& Mbura, J. (2015). Identification of Reasons for and Socio-Economic Impacts of Persistent Floods in Dar es Salaam. World Journal of Social Science Research. https://doi.org/10.22158/wjssr.v2n2p180

Dalu, M. T., Charles, S. M., \& Dalub, T. (2018). Influence of land cover, proximity to streams and behold Topographical location on flooding impact in informal settlements in the Eastern Cape, South Africa. International Journal of Disaster Risk Reduction, 28, 481-490. https://doi.org/10.1016/j.ijdrr.2017.12.009

Danso, S., \& Yeboah, I. (2019). Coping strategies of households affected by flooding: A case study of SekondiTakoradi Metropolis in Ghana. Addosasters, 36(3), 477-494.

Devkota, R. P., Cockfield, G., \& Maraseni, T. N. (2014). Perceived community-based flood Adaptation strategies under climate change in Nepal. Int. J. Global Warming, 6(1), 113-124. https://doi.org/10.1504/IJGW.2014.058758

Forsyth, T. (2013). Community-based adaptation: A review of past and future challenges (Vol. 4). Wiley interdisciplinary reviews: Climate Change. https://doi.org/10.1002/wcc.231

GFDRR (Global Facility for Disaster Reduction and Recovery). (2016). Disaster Risk Profile Zanzibar. The International Bank for the reconstruction of development the World Bank group. U.S.A.

GFDRR (Global Facility for Disaster Reduction and Recovery). (2018). Disaster Risk Profile Zanzibar. The International Bank for the reconstruction of development the World Bank group. U.S.A.

Hamidi, A., Wang, J., Guo, S., \& Zeng, Z. (2020). Flood vulnerability assessment using move framework: a case study of the northern part of district Peshawar, Pakistan, Natural Hazards (Vol. 101, pp. 385-408). https://doi.org/10.1007/s11069-020-03878-0

Jackson, II., Ronald, L., Drummond, Darlene, K., \& Camara, S. (2007). What Is Qualitative Research? Qualitative Research Reports in Communication, 8(1), 21-28. https://doi.org/10.1080/17459430701617879

John, R. (2020). Flooding in Informal Settlements: Potentials and Limits for Household Adaptation in Dar es Salaam City, Tanzania. American Journal of Climate Change, 9, 68-86. https://doi.org/10.4236/ajcc.2020.92006

Jonkman, S., \& Kelman, I. (2005). An analysis of the causes and circumstances of flood disaster deaths. Disasters, 29(1), 75-97. https://doi.org/10.1111/j.0361-3666.2005.00275.x

Lukamba, M. T. (2010). Natural disaster in African countries: what can we learn about them? The Journal for Transdisciplinary research in southern Africa, 6(2), 478-495. https://doi.org/10.4102/td.v6i2.266

Makame, O. M., \& Mwevura, H. (2019). Vulnerability and Adaptation strategies of coastal Communities to associated impacts of sea-level rise and coastal flooding, studies on Social-Ecological systems, vulnerability, Resilience and governance. Climate change and Costal resources in Tanzania. pp. 35-51. https://doi.org/10.1007/978-3-030-04897-6_3

Maro, F. (2008). Tanzania mainland and Zanzibar Island socio-economic and environment study, economic and social research foundation. Retrieved from www.or.tz.org

Mbura, J. (2014). Disaster management and persistent flooding disaster in Dar es Salaam. A dissertation submitted in partial fulfilment of the requirements for the degree of masters of social work (s.w) of the open university of Tanzania.

Mulwa, M. (2013). The community awareness and preparedness for floods along the lower Tana River, Tana River County. A Project Report Submitted in Partial Fulfilment of the Requirements for the Degree of Master of Arts in Environmental Planning and Management. Department of Geography and Environmental Studies. University of Nairobi.

Munyai, R., Musyoki, A., \& Nethengwe, N. (2019). An assessment of flood vulnerability and adaptation: A case study of Hamutsha-Muungamunwe village, Makhado municipality. Jamba journals of disaster risk studies, 11(2), 692. https://doi.org/10.4102/jamba.v11i2.692

Murtinho, F. (2016). What facilitates adaptation? An analysis of community-based adaptation to environmental 
change in the Andes. International Journal of the Commons, 10, 119-141. https://doi.org/10.18352/ijc.585

Næss, L. O., Bang, G., Eriksen, S., \& Vevatne, J. (2005). Institutional adaptation to climate change: flood responses at the municipal level in Norway. Glob Environ Change, 15(2), 125-138. https://doi.org/10.1016/j.gloenvcha.2004.10.003

Nguimalet, C. (2018). Comparison of community-based adaptation strategies for droughts and floods in Kenya and the Central African Republic. Water International, 43(1), 1-22. https://doi.org/10.1080/02508060.2017.1393713

Nyakundi, H., Mogere, S., Mwanzo, I., \& Yitambe, A. (2010). Community perceptions and response to flood risks in Nyando District, Western Kenya. Journal of Disaster Risk Studies, 3(1), 346-366. https://doi.org/10.4102/jamba.v3i1.35

Pradita, L., \& Ariyaningsih. (2018) Factors Affecting Vulnerability to Flood Risk (Case Study: Flood Risk in Balikpapan City). Retrieved from https://www.researchgate.net/publication/336275966

Qasim, S., Shrestha, R., \& Qasim, M. (2015). Risk perception of the people in the flood-prone. Khyber Pakhtunkhwa province of Pakistan. International Journal of Disaster Risk Reduction. 14, pp 373-378. https://doi.org/10.1016/j.ijdrr.2015.09.001

Sakijege, T., Sartohadi, J., Marfai, M. A., Kassenga, G. R., \& Kasala, S. E. (2019). Assessment of adaptation strategies to flooding: A comparative study between informal settlements of Keko Machungwa in Dar es Salaam, Tanzania and Sangkrah in Surakarta, Indonesia. Jàmbá: Journal of Disaster Risk Studies, 6(1). https://doi.org/10.4102/jamba.v6i1.131

Shah, A., Ye, J., Abid, M., Khan, J., \& Amir, S. (2018). Flood hazards: household vulnerability and resilience in disaster-prone districts of Khyber Pakhtunkhwa province, Pakistan. Nature Hazards, 93, 147-165. https://doi.org/10.1007/s11069-018-3293-0

Shaw, R. (2006). Critical Issues of Community Based Flood Mitigation: Examples from Bangladesh and Vietnam. Journal of Science \& Culture, 72(1-2).

Sheheli, M. K. (2015). Coping strategies of women in flood-prone areas of Bangladesh. Progressive agriculture, 26, 155-167. https://doi.org/10.3329/pa.v26i2.25977

Tanzania flood report. (2016). 3dead, 100s, displaced after the flood in Mbeya, Zanzibar and Kilimanjaro Regions.

Tran, K. H. (2014). Community-Based Adaptation Strategy for The Urban Poor under A Changing Climate a Case Study of Flooding in Ho Chi Minh City. PhD thesis RMIT University. Retrieved from http:researchbank.rmit.edu.au/serve/rmit:160809/TRAN

Tripathi, P. (2015). Flood Disaster in India: An Analysis of trend and Preparedness. Interdisciplinary Journal of Contemporary Research, 2(4).

Trogrlić, R. S., Wright, G. B., Adeloye, A. J., Melanie, J. D., \& Mwalee, F. (2018). Taking stock of communitybased flood risk management in Malawi. Environmental Hazards, 17(2), 107-127. https://doi.org/10.1080/17477891.2017.1381582

URT. (2013). Population and housing census, Population Distribution by Administrative Areas 2012. The United Republic of Tanzania, Dar es Salaam, Tanzania.

World Bank. (2008). United Republic of Tanzania country Data profile. Word bank.

Yamashita, S., Watanabeb, R., \& Shimatani, Y. (2015). Mitigating Urban Flood Disasters as One Way to Smartly Adapt to Climate Change in Japanese Cities. International review for spatial planning and sustainable development, (4), 2187-3666. https://doi.org/10.14246/irspsd.4.2_18

ZDMC. (2017). Zanzibar Disaster Management Commissioner. Report on the Effect of Heavy rainfall. Zanzibar Tanzania.

\section{Copyrights}

Copyright for this article is retained by the author(s), with first publication rights granted to the journal.

This is an open-access article distributed under the terms and conditions of the Creative Commons Attribution license (http://creativecommons.org/licenses/by/4.0/). 